\title{
Mutation Report
}

\section{$\mathrm{G} \rightarrow \mathrm{A}$ TRANSITION AT NUCLEOTIDE $2110 \mathrm{IN}$ THE HUMAN PLATELET GLYCOPROTEIN (GP) IX GENE RESULTING IN ALA ${ }^{139}($ ACC $) \rightarrow$ THR(GCC) SUBSTITUTION}

\author{
Tomohiro HAYASHI, ${ }^{1, *}$ Keijiroh SUZUKI, ${ }^{1}$ Jiroh AKIBA, ${ }^{1}$ \\ Akito Yahagr, ${ }^{1}$ Katsushi Tajma,,${ }^{1}$ Shinji SatoH, ${ }^{2}$ \\ and Hideo SASAKI ${ }^{1}$ \\ ${ }^{1}$ Third Department of Internal Medicine and ${ }^{2}$ Division of Blood \\ Transfusion, Yamagata University School of Medicine, \\ 2-2-2 Iida-Nishi, Yamagata 990-23, Japan
}

Key Words platelet glycoprotein IX, platelet membrane receptor, polymorphism, BstEII

The glycoprotein (GP) IX is a platelet membrane-associated protein and forms an $1: 1$ non-covalent complex with $\mathrm{GP} \mathrm{Ib}$, a heterodimeric transmembrane protein consisting of a disulfide linked $140 \mathrm{kD} \alpha$ chain and $22 \mathrm{kD} \beta$ chain (Roth, 1991). This GPIb/IX complex serves as a receptor for plasma von Willebrand factor ( $v W F$ ) to mediate platelet adhesion to the damaged vascular wall (Lopez, 1994). The GPIb $\alpha$ chain provides the $\mathrm{VWF}$ binding site, but the individual contribution of GPIX to adherence is unclear. GPIX is a relatively small ( $\mathrm{Mr}$ $20,000)$ surface protein, and employed in the efficient membrane expression of a functional GPIb/IX complex (Lopez et al., 1992). The gene of GPIX has been cloned and mapped to chromosome 3 (Hickey et al., 1990; Hickey and Roth, 1993). Genetic analyses of the patients with Bernard-Soulier syndrome (BSS), a hereditary qualitative platelet disorder characterized by a quantitative and/or qualitative abnormality of the GPIb/IX complex, revealed that the abnormality of the GPIX gene was able to cause BSS (Wright et al., 1993; Clemetson et al., 1994). In the course of GPIX gene analysis, we found a novel variant of a $G \rightarrow A$ transition at nucleotide 2110 resulting in $\mathrm{Ala}^{139}(\mathrm{GCC}) \rightarrow \operatorname{Thr}(\mathrm{ACC})$ replacement. Relationship between this variant and BSS phenotype was also studied in this report.

Polymerase chain reaction (PCR) was performed to amplify the region of the

Received November 29, 1996; Revised version accepted February 12, 1997.

* To whom correspondence should be addressed. 
GPIX gene encompassing the variant site. The primers used for PCR were as follows:

GPIXLi-9; 5'-TCACCTATCTGCGCCTCTGGCTGGAG-3',

GPIXLi-10; 5'-GCTGACCAGGCTTGGTGGAGTCTGGG-3',

which corresponds to nucleotide 1925-1950 for GPIXLi-9 and 2232-2257 for GPIXLi-10 (GenBank HUMGPIX, M80478). The PCR amplification was performed by a DNA thermal cycler (Perkin Elmer Cetus, Norwalk, CT) with $2.5 \mathrm{U}$ of Taq DNA polymerase (Takara, Kyoto) in a total volume of $100 \mu 1$ of standard PCR buffer containing $500 \mathrm{ng}$ of the genomic DNA, 50 pmol of each primer and $10 \%(\mathrm{v} / \mathrm{v})$ dimethyl sulfoxide. After subcloning the amplified fragments into the pGEM-T vectors (Promega, Madison, WI), nucleotide sequencing was performed using Deaza G/A T7 Sequencing Kits (Pharmacia, Uppsala, Sweden) with a primer complementary to the vector or the insert sequence. Figure $1 \mathrm{~A}$ showed a variant allele sequence with a $\mathrm{G} \rightarrow \mathrm{A}$ transition at nucleotide 2110 of the GPIX gene. Notes that this transition creates a new BstEII site on the PCR fragment (Fig. 1B, upper).

An allele-specific restriction enzyme analysis was performed to detect this variant in Japanese. Genomic DNAs from unrelated 53 healthy individuals were amplified by PCR using above mentioned primers. The obtained PCR fragments

A。

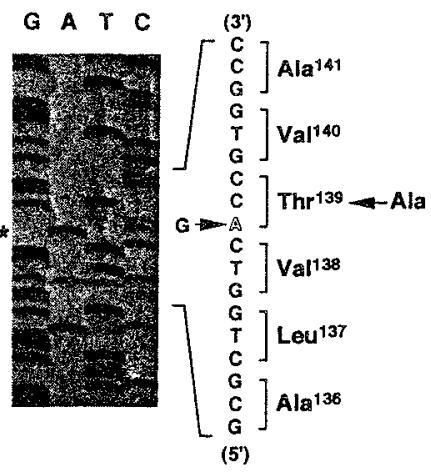

B.
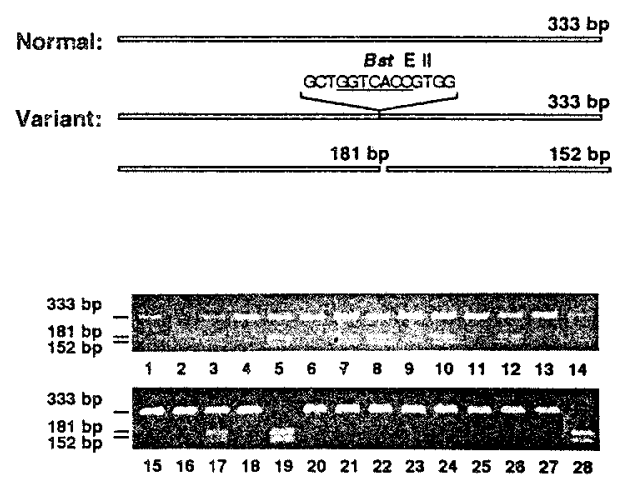

Fig. 1. A. Autoradiograph illustrating a variant DNA sequence. The observed variant sequence is shown. $G \rightarrow A$ transition at nucleotide 2110 results in $\mathrm{Ala}^{139}(\mathrm{GCC})$ $\rightarrow \operatorname{Thr}(\mathrm{ACC})$ substitution. An asterisk denotes a variant band. B. Allelespecific restriction analysis of the $\mathrm{PCR}$ products. (Upper) Schema of BstEII digestion of the PCR fragments. $G \rightarrow A$ transition at nucleotide 2110 creates a new BstEII restriction site (underlined). After treatment of the PCR fragments with BstEII, a variant allele produces 181 -bp and 152-bp fragments. (Lower) The amplified 333-bp PCR fragments were digested with BstEII, and analyzed by electrophoresis through a $2.5 \%$ agarose gel. Patterns of DNA digests from 26 individuals are shown. Corresponding molecular sizes are shown at left side. Lane 1: not digested. Lanes 3-28: digested with Bst EII. 
were digested with an endonuclease BstEII (Takara, Kyoto) and analyzed by electrophoresis through a $2.5 \%$ agarose gel (Fig. 1B, lower). Out of 53 individuals examined, 30 were homozygous for $G / G$ and 19 were heterozygous for G/A. Only 4 individuals were homozygous for $\mathrm{A} / \mathrm{A}$. The allelic frequency, estimated from 53 unrelated Japanese, is as follows: for the $2110 \mathrm{G} / \mathrm{A}$ variation in the GPIX gene, $\mathrm{G}=0.75$ and $\mathrm{A}=0.25$.

This $\mathrm{G} \rightarrow \mathrm{A}$ transition results in $\mathrm{Ala}^{139} \rightarrow$ Thr substitution. Both Ala and Thr have aliphatic side chains, but the hydroxyl group of Thr side chain makes it more hydrophilic. Since Ala resides within a transmembrane domain of the GPIX polypeptide (Hickey et al., 1989), Ala ${ }^{139} \rightarrow \mathrm{Thr}$ substitution may result in an insufficient surface expression of the GPIb/IX complex. Four individuals homozygous for A/A were analyzed their surface expression of the GPIb/IX complex by a fluorescence-activated cell sorter (FACS). Ristocetin-induced platelet agglutination test (RIPA) (Kinlough-Rathobone et al., 1983) were also performed to analyze if the functional GPIb/IX complex occurred on the platelet surface. Both FACS analysis and RIPA failed to show different patterns from normal (data not shown), therefore, the $G \rightarrow A$ transition described here is again confirmed as a BstEII polymorphism of the GPIX gene with $\mathrm{Ala}^{139} \rightarrow \mathrm{Thr}$ substitution. This BstEII polymorphism will be useful for analyzing the GPIX gene or for a linkage analysis as an intragenic marker.

Acknowledgments We are grateful to Miss Tomoko Takahashi for her help in preparing human genomic DNAs.

\section{REFERENCES}

Clemetson JM, Kyrle PA, Brenner B, Clemetson KJ (1994): Variant Bernard-Soulier syndrome associated with a homozygous mutation in the leucine-rich domain of glycoprotein IX. Blood 84: 1124-1131

Hickey MJ, Williams SA, Roth GJ (1989): Human platelet glycoprotein IX: an adhesive prototype of leucine-rich glycoproteins with flank-center-flank structures. Proc Natl Acad Sci USA 86: 6773-6777

Hickey MJ, Deaven LL, Roth GJ (1990): Human platelet glycoprotein IX. Characterization of cDNA and localization of the gene to chromosome 3. FEBS Lett 274: 189-192

Hickey MJ, Roth GJ (1993): Characterization of the gene encoding human platelet glycoprotein IX. I Biol Chem 268: 3438-3443

Kinlough-Rathobone RL, Packham MA, Mustard JF (1983): Platelet aggregation. In: Harker LA, Zimmerman TS (eds). Measurements of platelets function. Churchill Livingstone, New York, pp 64-91

Lopez JA, Leung B, Reynolds CC, Li CQ, Fox JE (1992): Efficient plasma membrane expression of a functional platelet glycoprotein Ib-IX complex requires the presence of its three subunits. J Biol Chem 267: 12851-12859

Lopez JA (1994): The platelet glycoprotein Ib-IX complex. Blood Coag Fibrinol 5: 97-119

Roth GJ (1991): Developing relationships: arterial platelet adhesion, glycoprotein Ib, and leucine-rich glycoproteins. Blood 77: 5-19

Wright SD, Michaelides K, Johnson DJ, West NC, Tuddenham EG (1993): Double heterozygosity for mutations in the platelet glycoprotein IX gene in three siblings with BernardSoulier syndrome. Blood 81: 2339-2347

Vol. 42, No. 2, 1997 